Zofia KęPińSKa-WALCZAK

\title{
WYZWANIA STOJĄCE PRZED NAUCZANIEM RELIGII WE WSPÓŁCZESNEJ SZKOLE
}

The challenges of religion teaching in contemporary school

\section{Wprowadzenie}

Każde miejsce i czas posiada swój indywidualny kontekst społeczno-kulturowy. Ten kontekst kształtuje społeczeństwo, a zatem ma niezaprzeczalny wpływ na osobę. Wychowanie i kształcenie szkolne dzieci i młodzieży, w tym także nauczanie religii, musi uwzględniać, odczytywać ten kontekst i odpowiadać na niego. Człowiek zawsze żyje w konkretnej kulturze i pod jej wpływem ${ }^{1}$. Nie można zrozumieć człowieka, nie biorąc tego pod uwagę. Znajomość kultury ma kluczowe znaczenie i niejednokrotnie przesądza o tym, czy katechetyczny akt komunikacji będzie skuteczny ${ }^{2}$.

Dziśs przed nauczycielem religii pojawiają się zupełnie nowe wyzwania, inne niż te sprzed dwudziestu czy nawet dziesięciu lat. Dynamika przemian społecznych oraz kulturowych wymaga od katechety nieustannego ich rozpoznawania, odczytywania „znaków czasu” i przekładania wyników obserwacji na obszar swojego działania, czyli w tym wypadku - nauczanie religii w szkole. Biorąc pod uwagę kontekst społeczno-kulturowy, nauczyciel religii musi pamiętać, że każdy w tym kontekście funkcjonuje inaczej. Jeden uczeń może być mocno determinowany kulturą, w której żyje, inny zaś przeciwnie - może

1 Por. GS 53: „Do istoty człowieka należy to, że do prawdziwego i pełnego człowieczeństwa dochodzi on jedynie poprzez kulturę (...)”.

2 Zob. R. Czekalski, Katecheza komunikacja wiary, Płock 2006, s. 186. 
manifestować wobec niej bunt, co charakterystyczne jest zwłaszcza dla młodzieży w okresie dojrzewania.

Podsumowując, katecheta musi mieć na uwadze dwie rzeczy: kontekst społeczno-kulturowy o szerokim znaczeniu oraz oddziaływanie tego kontekstu na każdego z uczniów, z uwzględnieniem tego, co najbardziej indywidualne. Można mówić zatem o kontekście globalnym oraz o uwarunkowaniach indywidualnych. Tylko biorąc jedno i drugie pod uwagę, nauczyciel religii może trafić do uczniów z Ewangelią. W niniejszym artykule spróbuję odpowiedzieć na pytanie, jakie nowe wyzwania stoją dziś przed nauczycielami religii w szkole i jakie działania powinny być konsekwencją tych wyzwań.

\section{Charakterystyka wyzwań, na jakie natrafia nauczyciel religii}

Wiele jest dziś czynników, które zakłócają docieranie Dobrej Nowiny do człowieka, zwłaszcza młodego, który dopiero zaczyna uczyć się dokonywania wyborów, podejmowania decyzji, rozróżniania między tym, co wartościowe a tym, co tylko z pozoru jest dobre. Żyjemy w dobie wielości „prawd”. W tym pluralizmie „prawd”, w chaosie codziennego życia, człowiek gubi to, co istotne. Błądzi na gruncie wyboru wartości, na gruncie własnej wiary, wierzy jak gdyby „po omacku”, nie bardzo wiedząc, za czym ma podążać. W Dyrektorium ogólnym o katechizacji napisano, że „wobec tej złożonej sytuacji może się zdarzyć, że wielu chrześcijan będzie odczuwało zakłopotanie i zagubienie się, nie umiejąc sobie poradzić w różnych sytuacjach ani ocenić orędzi, jakie w nich występują, bądź porzuci regularne praktyki religijne i będzie żyło tak, jakby Bóg nie istniał, często uciekając się do zastępczych form pseudoreligijnych"3.

Istnieje dziś także pewne przewartościowanie, zwrot bardziej ku „mieć” niż „być” i związana z tym presja posiadania, której doświadcza nawet małe dziecko ze strony rówieśników. Czasy, w których żyjemy są nacechowane konsumpcjonizmem i wszechobecną technicyzacją. Dostęp do informacji, obszernego katalogu treści i obrazów - dziś tak olbrzymi, jak nigdy dotąd - wywiera na młodego człowieka realny

${ }^{3}$ DOK 193. 
wpływ. Młodzież kreuje swój styl życia niejednokrotnie pod wpływem tego, co widzi w mediach. Problemem jest także seksualizacja dzieci i młodzieży. Treści seksualne dostępne są nie tylko w mediach, ale też w przestrzeni publicznej, chociażby w reklamie. Model szkolnego wychowania seksualnego, jaki już funkcjonuje w wielu krajach europejskich i dociera także na polski grunt, dostarcza negatywnych wzorców i pokazuje wizję seksualności sprzeczną z chrześcijańską wizją człowieka. Czystość jest dziś passé, a presja grupy w tym zakresie jest olbrzymia. Często młody człowiek nie przyznaje się w grupie rówieśników, że nie jest aktywny seksualnie, że wyznaje w tej kwestii pewne zasady, ponieważ boi się wyśmiania. To rzeczywiście praradoks, że współczesny człowiek tak często wstydzi się tego, co dobre, a obnosi się z tym, co złe.

Człowiek XXI wieku, zagubiony w otaczającej go rzeczywistości, w gąszczu obrazów i treści, nie potrafiący odczytać znaków czasu, staje się często jedynie biernym uczestnikiem - a nawet tylko obserwatorem - własnego życia. Już Paweł VI przestrzegał: „Życie nasze jest dzisiaj bardzo zajęte wizją świata zewnętrznego. Środki łączności tak się rozrosły, stały się tak agresywne, że wciągają nas, że odrywają i odłączają od nas samych, pozbawiając świadomości osobowej. Uważajmy! Możemy przejść z pozycji zwykłych obserwatorów na pozycję krytyków, ludzi myślących i sędziów. Postawa świadomości myślącej jest dla dzisiejszego człowieka niezmiernie ważna, jeśli chce on zostać żywym człowiekiem, a nie zwykłym ekranem, na który padają tysiące obrazów"4.

W takiej rzeczywistości, której charakterystykę nakreślono powyżej, egzystuje uczeń, do którego katecheta ma trafić z ewangelicznym przekazem. Wiele jest czynników, które to utrudniają, a które zostały wyżej wymienione. Konsumpcjonizm, wypieranie „być” przez „mieć”, seksualizacja, wpływ mediów. W tym właśnie katecheta powinien widzieć wyzwanie, które motywuje go do podejmowania nowych działań, poszukiwania rozwiązań i dróg dotarcia do młodego człowieka.

4 Paweł VI, Odczytanie znaków czasu. Rozważanie w czasie Audiencji Generalnej (16 IV 1969 r.), w: Paweł VI, Trwajcie mocni we wierze, t. 2, Kraków 1974, s. 561-564. 


\section{Propozycje skutecznych działań katechety w obliczu aktualnych wyzwań}

Jak już zostało powiedziane we wprowadzeniu, katecheta, chcąc trafić z Ewangelią do uczniów, musi mieć na uwadze zarówno szeroki kontekst społeczno-kulturowy, w którym uczniowie funkcjonują, jak i indywidualne czynniki, jakie mają wpływ na każdą pojedynczą osobę. Katecheta powinien wiedzieć, jak każdy z uczniów odnajduje się w bieżącym kontekście kulturowo-społecznym, na ile jest przez niego determinowany. Musi także zdawać sobie sprawę z indywidualnych uwarunkowań, takich jak środowisko, w którym uczeń się wychowuje, sytuacja rodzinna, poziom jego religijności czy cechy charakteru. To oczywiste, ale warte przypominania: katecheta musi znać swoich uczniów, ale by ich znać, musi być stale otwarty na dialog. Dialog jest kluczowy we wszelkich relacjach międzyludzkich. A skoro o dialogu mowa, nie sposób nie wspomnieć o godności człowieka, bo jest ona tym, co dialog zawsze musi uwzględniać.

Godność człowieka może być punktem wyjścia w nauczaniu religii. Godność jest tym, co katecheta powinien widzieć i szanować w każdym $\mathrm{z}$ uczniów, a zarazem tym, o czym powinien im mówić w wielu kontekstach. Rozważmy taki przykład: uczeń spiera się z katechetą w kwestii współżycia przedmałżeńskiego. Jakich używa argumentów? Mówi, że dziś wszyscy tak robią, że małżeństwo to tylko formalność, że on jest wolnym człowiekiem i ma prawo, że to właściwie jego sprawa i nikogo nie powinno to obchodzić, itd. Co może powiedzieć katecheta? Może powołać się na szóste przykazanie, może cytować Katechizm Kościoła Katolickiego, może rozwinąć wątek grzechu i kary. Czyli sprowadzić temat do kwestii prawa, nakazów i zakazów. To najprawdopodobniej ostatnia rzecz, która przekona młodego człowieka, zwłaszcza gdy przeżywa okres buntu. Cóż wtedy mogą go obchodzić zakazy? Jaki grzech? On i tak nie chodzi do spowiedzi, a zakazy są po to, by je łamać. Mądry, empatyczny katecheta może odpowiedzieć jednak inaczej: „Tak, masz rację, jesteś wolnym człowiekiem. Rzeczywiście, to twoje życie i twoja sprawa. Ale właśnie dlatego, że to twoje życie, niepowtarzalne i jedyne, zadbaj o nie, zatroszcz się. Bo masz w sobie olbrzymią godność. Jesteś wyjątkowy, jesteś 
prawdziwą wartością". Taki sposób prowadzenia rozmowy ma zdecydowanie większe szanse nawiązania porozumienia z uczniem. Na godność człowieka katecheta może i powinien stale się powoływać. Bóg nikogo nie potępia, ale szuka go i woła po imieniu, bo wciąż widzi w nim tę niepowtarzalną wartość. Dobrze opisał to ks. Józef Tischner: „Istotne jest to, że ty jesteś ty. Jeśli Ty zginiesz, nikt cię nie zdoła zastąpić. (...) To Ty wymaga ochrony"5.

Kolejnym aspektem, o którym powinien pamiętać katecheta, jest kwestia ludzkiej wolności. Młody człowiek jest na tę wolność szczególnie wrażliwy, manifestuje to, że jest wolny: wolny w wyborze sposobu spędzania wolnego czasu, w doborze przyjaciół, wolny w decydowaniu o swojej seksualności, a także w wyborze światopoglądu i religii. Współcześnie właśnie do wolności człowieka tak wielu się odwołuje. Rzeczywiście, katecheta może bez obaw przyznać uczniowi rację, że wolność to kwestia fundamentalna. Przecież to Bóg dał człowiekowi wolną wolę, a zatem człowiek może odrzucić samego Boga. To jeden $\mathrm{z}$ argumentów potwierdzających opisaną wcześniej ludzką godność. Bez wolności człowiek nie może być w pełni sobą. Tylko wybory dokonywane z głębi naszej wolności są wyborami dojrzałymi. Wiary nie można człowiekowi narzucić, nie można jej nauczyć. Można do wiary wychowywać, nakierowywać na nią. Ale człowiek sam musi wybrać, dać odpowiedź ${ }^{6}$. Młodego człowieka łatwiej przekonać, apelując do jego wolności, niż odwołując się do nakazów i zakazów, do których może mieć z góry sceptyczne nastawienie. Jeśli sam Bóg szanuje wolną wolę człowieka, czy można więc tę kwestię pomijać, nauczając religii? Odpowiedź jest oczywista.

Kontekst społeczno-kulturowy, wszystko to, co charakteryzuje naszą ponowoczesną epokę, powinno rodzić w nauczycielu religii potrzebę pogłębionej formacji i zdobywania coraz szerszej wiedzy o aktualnych problemach, jak choćby tych związanych z seksualnością człowieka. O ile bowiem nauczanie religii młodszych dzieci

\footnotetext{
5 J. Tischner, Miłość niemiłowana, Kraków 1993, s. 46-47.

6 Por. A. Binz, Katecheta: misja, zawód czy powołanie?, w: W służbie człowiekowi. Studium duszpastersko-katechetyczne, red. Z. Marej SJ, Kraków 1991, s. 90n.
} 
może koncentrować się na historii życia Jezusa, uczeniu Dekalogu i formowaniu pewnej, adekwatnej do wieku, wrażliwości religijnej, o tyle starsze dzieci i młodzież chętniej poruszają tematy właśnie związane ze sferą seksualną i bieżącymi kontrowersjami obecnymi w mediach, jak np. związki partnerskie, aborcja, eutanazja. Katecheta musi mieć świadomość, że nieraz uczniowie będą, z przekonania czy potrzeby prowokacji, wygłaszać opinie sprzeczne z tym, czego naucza Kościół, zwłaszcza właśnie w kwestiach etycznych. Dlatego tak ważne jest, by katecheta dysponował rzetelną wiedzą, a jego argumenty nie kończyły się na Dekalogu, ale były przekonywujące również dla tych najbardziej sceptycznych. Przykładem może być dyskusja o aborcji. Argumentem przeciwko niej jest nie tylko fakt, że to Bóg daje życie i decyduje o jego końcu, ale też naukowe dowody na to, że człowiek od poczęcia jest w pełni człowiekiem i ze względów etycznych wymaga ochrony. Katecheta powinien więc być w pewnym sensie współczesnym apologetą.

Doświadczenie pokazuje, że istnieją pewne wskazania, które są uniwersalne i pasują do każdych czasów. Chodzi o takie metody nauczania religii, które ułatwią dotarcie do uczniów z przekazem ewangelicznym. Pierwszą metodą jest zadawanie pytań. „Widzisz, Menonie, że ja go nic nie uczę, tylko pytam go o wszystko"7 - mówi Sokrates do Menona, pokazując, jak ważne w procesie nauczania, także religii, jest zadawanie pytań. Kierując się tą sokratejską (aporetyczną) metodą nauczania, katecheta powinien do ucznia kierować pytania. Nie pytamy jedynie po to, żeby sprawdzić wiedzę, również tę religijną. ${ }^{8}$ Pytamy przede wszystkim w celu pobudzenia refleksji. Po otrzymaniu pytania w umyśle ucznia rozpoczyna się pewien proces, który przebiega etapowo. Uczeń na początku ma wrażenie,

\footnotetext{
7 Platon, Menon, w: Platon, Dialogi, Kęty 2005, t. I, s. 477.

8 Wiedzę religijną można rozumieć dwojako: jako faktyczną wiedzę np. o wydarzeniach biblijnych, o historycznych dowodach na życie Jezusa, o historii i nauce Kościoła, a także jako swego rodzaju filozofowanie, rozumowe poszukiwanie argumentów przejawiających na korzyść wiary, bo przecież fides quarens intellectum, jak głosi znana augustyńska formuła.
} 
że zna odpowiedź. Ten etap można nazwać etapem wiedzy pozornej. Jednak idąc dalej w refleksję nad pytaniem, odkrywa, poszukując najcelniejszej odpowiedzi, że oto nic nie wie. Tak, jak chłopak, któremu Sokrates zadawał szereg pytań, i który przyznał ostatecznie: „Ależ, na Zeusa, Sokratesie, ja nie wiem”. Dopiero wówczas rodzi się w nim pragnienie, żeby zdobyć wiedzę. Rodzi się w nim chęć poznania, „(...) teraz może on i szukać będzie z przyjemnością, skoro nie wie (...)"10. Dopóki myślał, że wie, choć nie wiedział, dopóty nie mogło w nim być chęci szukania wiedzy. Żył bowiem w przeświadczeniu, że już ją posiada. Dopiero, gdy popadnie w biedę i zda sobie sprawę, że tej wiedzy nie ma, może odnaleźć w sobie pragnienie jej zdobycia $^{11}$. To uświadomienie sobie własnej niewiedzy może być bolesnym doświadczeniem. Tak jest najczęściej, gdy człowiek staje w prawdzie o sobie samym. Katecheta powinien dołożyć starań, by to uświadomienie przez ucznia owego braku, owej niewiedzy, nie wywołało zniechęcenia, ale przeciwnie - by było motywacją do podjęcia trudu zdobycia wiedzy. Niejednokrotnie wystarczy tu umiejętność zarażenia własnym zapałem poznawania i przyznania, że choć jest się nauczającym, to jednak nadal samemu pozostaje się $\mathrm{w}$ procesie uczenia się i własnego formowania. Otóż, zadając pytanie, nauczyciel może zarazem sam odkrywać samego siebie, może to służyć odkrywaniu jego własnej drogi ewangelicznego wzrastania. Może zarazem wzbudzić zaufanie ucznia - podobnie jak uczeń, on także jest w drodze, której na imię wiara; wciąż pyta, a nieraz nawet wątpi.

Kolejna metoda wiąże się z przyczyną celową i wskazywaniem tego, co pierwsze i uniwersalne. Postępując zgodnie ze wskazaniami kolejnego wielkiego filozofa - Arystotelesa, katecheta powinien wskazywać uczniowi istotę, sedno sprawy. Powinien uwrażliwić go na poszukiwanie przyczyny celowej (causa finalis) - powstawanie rzeczy

\footnotetext{
9 Platon, Menon, dz. cyt., s. 479.

10 Tamże.

11 Zob. tamże: „Czy myślisz, że on by się przedtem brał do szukania lub uczenia się tego, co uważał, że wie, choć nie wiedział, zanim nie popadł w biedę, nie uwierzył, że nie wie, i nie zapragnął wiedzy?"
} 
musi bowiem służyć pewnemu celowi. Przyczyna celowa według Arystotelesa jest „tym, ze względu na co” powstaje byt ${ }^{12}$. Cel, dla którego wszystko należy czynić, co się czyni, to Dobro. Arystoteles, mówiąc o uczeniu, wskazywał kierunek od rzeczy jednostkowych do zasad ogólnych. Należy pomóc uczącemu się dojść od rzeczy jednostkowej do tego, co uniwersalne. Dopiero wtedy można mówić o sztuce, która według Arystotelesa tym się różni od doświadczenia, że „doświadczenie jest poznaniem poszczególnych przypadków, natomiast sztuka - tego co ogólne"13. Katecheta powinien pomóc uczniowi opanować sztukę właśnie, ponieważ jedno doświadczenie, powstałe z wielokrotnego zapamiętywania tej samej rzeczy, nie wystarczy. Oczywiście, doświadczenie jest niezbędne, co Arystoteles podkreślał. Ale by mówić o nauce, potrzebne jest jeszcze rozumienie i umiejętność dopasowania wiedzy do zastanych sytuacji. „Sztuka [bowiem] powstaje wtedy, gdy z wielu doświadczalnych ujęć tworzy się jedno ogólne, odnoszące się do przypadków sobie podobnych"14. Uczeń musi umieć to, co wie, dopasować do tego, co widzi, a także wiedzieć, dlaczego coś jest, a nie tylko, że jest. Można chyba nazwać to umiejętnością rozpoznawania znaków czasu. Potrzeba, by uczeń rozwijał w sobie zdolność logicznego myślenia, wnikliwej obserwacji i wnioskowania. Zadaniem katechety jest nakierowywać ucznia, pokazywać, ale nie wyręczać w samodzielnym myśleniu i działaniu. Tylko ten, kto nauczy się samodzielności, może podjąć próbę zrozumienia porządku świata. A zatem nauczający powinien: naprowadzać myślenie ucznia na to, co pierwsze i podstawowe, wskazywać Dobro jako cel, by uczeń sam w tym Dobru wzrastał, i nakierowywać ucznia na to, co uniwersalne, aby potrafił on dochodzić do pewnych prawd i wniosków. Idąc dalej, można powiedzieć, że nauczyciel ma z ucznia wydobywać samodzielnego i dobrego człowieka i takiemu człowiekowi pokazywać Dobrą Nowinę i Boga jako najwyższe Dobro.

\footnotetext{
12 Arystoteles, Metafizyka, Lublin 1996. t. I, s. 19, (983).

13 Tamże, (981).

14 Tamże, (980).
} 
Następnym ważnym elementem jest motywowanie ucznia do działania. Każde nauczanie, także nauka religii, musi pobudzać do działania. Uczeń musi chcieć włączyć się w proces swego uczenia się, musi w tym procesie jakoś siebie i swoją rolę odnaleźć. Nie może to być rola biernego słuchacza, przepisującego i przyswajającego na pamięć formułki. Owszem, w ten sposób można przebrnąć przez cały proces nauki religii od szkoły podstawowej aż do końca liceum. Jednak z prawdziwym rozwojem religijności, dojrzewaniem wiary, ma to niewiele wspólnego. Aby ucznia pobudzić do działania, musimy - co zostało już powiedziane - pytać, ale też dawać do zrealizowania różne zadania i projekty, zarówno indywidualne, jak i wymagające pracy zespołowej. Można np. zaproponować napisanie eseju o tym, co każdego najbardziej urzeka w nauczaniu Jezusa, albo zaangażować uczniów w jakąś formę wolontariatu, np. pomoc bezdomnym, i pokazać to działanie w kontekście ewangelicznego opisu sądu, gdzie mowa jest o „Braciach najmniejszych”. Chodzi o to, by aktywizować na różne sposoby, pozostając otwartym na sugestie uczniów. W nauczycielu uczeń ma mieć przede wszystkim życzliwego przewodnika, szanującego autonomię ucznia i pozostawiającego mu miejsce na własne poszukiwania i błędy. Nauczyciel nie może być kimś, kto idzie krok przed swoim uczniem, wydeptując mu drogę i usuwając przeszkody, ale powinien być tym, który kroczy obok ucznia, owe przeszkody wskazując i pozwalając, by uczeń sam podjął trud ich pokonania.

W toku rozważań nad tym, jakie wyzwania stoją dziś przed nauczycielami religii, nasuwa się pewna wypowiedź księdza Józefa Tischnera, dotycząca dawania świadectwa. Tischner pisał: „Dałbyś świadectwo, stwarzając sytuację, w której domownik ma ochotę się nawrócić, ma ochotę iść do kościoła, żeby przeżyć i zobaczyć, co tam naprawdę się dzieje... To trochę tak jak wtedy, gdy ktoś zachwycony wraca $z$ teatru. Patrząc na niego, mam ochotę iść na tę sztukę, żeby przeżyć coś podobnego. Na tym polega istota świadectwa"15. Na nic nie zdadzą się zachęty i różne metody motywowania czy przekonywania ucznia,

15 J. Tischner, Miłość nas rozumie: rok liturgiczny z księdzem Tischnerem, Kraków 2001, s. 60 . 
jeśli nauczający sam nie będzie miał w sobie zapału do tego, co głosi. Kolejną wskazówką może więc być to, wydawałoby się, oczywiste spostrzeżenie: katecheta powinien promieniować autentycznym zapałem, udzielającym się innym. Nie musi to być spektakularne lub narzucające się. Wystarczy, żeby lubił to, czym się zajmuje, wierzył w to, co głosi i jednocześnie pozostawał otwarty na dialog, który jest podstawą wszelkich relacji i działania.

\section{Podsumowanie}

Dzisiejsza katecheza funkcjonuje w takim kontekście społeczno-kulturowym, w jakim funkcjonują przede wszystkim jej odbiorcy. Ten kontekst, a także indywidualne uwarunkowania dotyczące każdego z uczniów, muszą być znane katechecie, by mógł do uczniów dotrzeć z przekazem Ewangelii. Współczesny kontekst społeczno-kulturowy, a raczej jego składowe: konsumpcjonizm, seksualizacja, technicyzacja, pluralizm „prawd”, ale też podkreślenie wolności i autonomii człowieka, s. prawdziwym wyzwaniem dla formacji katechety i powinny wyzwalać w nim konkretne działania. W epoce, która tak wiele mówi o wolności i godności człowieka, również katecheta musi się do nich odwoływać i stale je podkreślać, a nade wszystko szanować w swych uczniach. W nauczaniu religii, będąc otwartym na dialog i współpracę z uczniami, katecheta powinien pobudzać uczniów do działania i własnej refleksji, zadając im pytania, prowadząc twórcze rozmowy i aktywizując ich na różne sposoby. Nauczyciel religii powinien uznać za swój obowiązek stałe poszerzanie swej wiedzy na temat bieżących spraw, a także pogłębianie własnej formacji duchowej. Ta formacja jest w tym kontekście najbardziej fundamentalną kwestią. Jeśli bowiem zabraknie autentycznego świadectwa, na nic się zdadzą inne działania. Katecheta w każdym miejscu i czasie musi żyć Ewangelią i przy każdej sposobności świadczyć o Chrystusie.

\section{Streszczenie}

W artykule poruszono temat wyzwań, jakie stoją przed nauczaniem religii we współczesnej szkole. Po ich scharakteryzowaniu podjęto próbę odpowiedzi na pytanie, jakie skuteczne działania może podjąć nauczyciel religii, by sprostać tym wyzwaniom. Zwrócono uwagę na konieczność poszanowania 
przez katechetę godności i wolności każdego z uczniów, otwartości na dialog oraz dawania przez niego autentycznego świadectwa.

\section{Summary}

The article discusses the challenges of religion teaching in contemporary school and attempts to answer the question: What can a religion teacher do in order to effectively meet these challenges? The need to respect the dignity and freedom of every student, being open to dialogue as well as giving true testimony by the teacher have been particularly emphasized.

Słowa kluczowe: nauczanie religii, katecheza, szkołą, godność, wolność, dialog, prawdziwe świadectwo

Key words: religion teaching, the challenges of religion teaching, school, dignity, freedom, dialogue, true testimony

\section{Bibliografia}

Arystoteles, Metafizyka, RW KUL, Lublin 1996.

Binz A., Katecheta: misja, zawód czy powołanie?, w: W służbie człowiekowi. Studium duszpastersko-katechetyczne, red. Z. Marek, Kraków 1991.

Czekalski R., Katecheza komunikacją wiary, Płock 2006.

Kongregacja ds. Duchowieństwa, Dyrektorium ogólne o katechizacji, Rzym 1997.

Paweł VI, Odczytanie znaków czasu. Rozważanie w czasie Audiencji Generalnej (16 IV 1969 r.), w: Paweł VI, Trwajcie mocni we wierze, t. 2 , WAM, Kraków 1973, s. 561-564.

Platon, Menon, w: Platon, Dialogi, Kęty 2005.

Sobór Watykański II, Gaudium et spes. Konstytucja duszpasterska o Kościele w świecie współczesnym, w: Sobór Watykański II, Konstytucje, dekrety, deklaracje, Poznań 2002.

Tischner J., Miłość nas rozumie: rok liturgiczny z księdzem Tischnerem, Kraków 2001.

Tischner J., Miłość niemiłowana, Kraków 1993. 


\section{Biogram:}

Zofia Kępińska-Walczak - mgr teologii, doktorantka teologii pastoralnej na UKSW, absolwentka Instytutu Wiedzy o Kulturze (obecnie: Instytut Dialogu Kultury i Religii) na UKSW w Warszawie, wolontariuszka w Stowarzyszeniu Rodzin i Opiekunów Osób z Zespołem Downa „Bardziej Kochani”, zainteresowania naukowe: duszpasterstwo nadzwyczajne, personalizm chrześcijański, religijność ludowa. 